Sains Malaysiana 50(12)(2021): 3631-3645

http://doi.org/10.17576/jsm-2021-5012-14

\title{
Poorer Attainment of Hemoglobin A1C, Blood Pressure and LDL-Cholesterol Goals among Younger Adults with Type 2 Diabetes
}

(Pencapaian Matlamat Hemoglobin A1C, Tekanan Darah dan Kolesterol LDL yang Lemah dalam Kalangan Orang Muda Dewasa yang Menghidap Diabetes Jenis 2)

\author{
Kim Sui Wan, Noran Naqiah Hairi*, FEISUl IDZWAn Mustapha, KhaliJah Mohd Yusof, Zainudin MOHD \\ Ali \& FoONG Ming MOY
}

\begin{abstract}
Concurrent attainment of glycated haemoglobin A1C, blood pressure, and LDL-cholesterol goals, or collectively known as the 'ABC' goals, help prevent cardiovascular complications in patients with type 2 diabetes (T2D). We aimed to determine the proportion of T2D patients who achieved all three ABC goals in Malaysia's public health clinics. We also determined the association between age groups with the attainment of all the ABC goals. A cross-sectional analysis of the baseline findings from a retrospective open cohort study between 2013 and 2017 in Negeri Sembilan, Malaysia was conducted. The data was extracted from the National Diabetes Registry. The primary outcome was the proportion of patients who attained all three ABC goals. The exposure of interest was patients' age groups, namely 18-44, 45-59 and $\geq$ 60 years. Multivariate logistic regression analysis was used to adjust demographics factors, comorbidities, complications and treatment profiles. Among 17,592 patients, the mean age was 59.1 years, with $56.3 \%$ females and $64.9 \%$ Malays. Overall, 4.5\% (95\% CI: 4.2-4.8) of the patients attained all the ABC goals. Compared to older adults aged $\geq 60$ years, patients aged 18-44 and 45-59 years had adjusted odds ratios of 0.50 and 0.72, respectively, to achieve all the ABC goals. Ethnicity, body mass index, diabetes treatment modality, lipid-lowering agent and polypharmacy were independent factors associated with the outcome. In summary, achieving all the ABC goals in T2D patients is challenging, especially among younger adults. Our findings suggest that more targeted interventions should be directed towards this high-risk subpopulation.
\end{abstract}

Keywords: Blood pressure; cholesterol; haemoglobin A1C; primary care; type 2 diabetes

\section{ABSTRAK}

Pencapaian sasaran hemoglobin A1C, tekanan darah dan kolesterol LDL yang juga dikenali sebagai sasaran 'ABC' mampu mencegah komplikasi kardiovaskular dalam kalangan pesakit diabetes jenis dua (T2D). Kajian ini bertujuan untuk mengenal pasti peratusan pesakit T2D yang mencapai kesemua tiga sasaran ABC di klinik kesihatan di Malaysia. Kami juga mengkaji hubungan antara kumpulan umur dengan pencapaian kesemua sasaran ABC. Satu analisis keratan rentas daripada penemuan kajian kohort retrospektif terbuka antara tahun 2013 sehingga 2017 di Negeri Sembilan, Malaysia telah dijalankan. Data telah diambil daripada pangkalan data National Diabetes Registry. Keputusan utama adalah peratusan pesakit yang mencapai kesemua tiga sasaran ABC. Pendedahan yang dikaji adalah kumpulan umur pesakit iaitu 18-44, 45-59 dan $\geq 60$ tahun. Analisis regresi logistik multivariat digunakan untuk mengawal faktor demografi, komorbiditi, komplikasi dan profil rawatan. Dalam kalangan 17,592 pesakit, min umur adalah 59.1 tahun, dengan 56.3\% jantina perempuan dan 64.9\% pesakit berbangsa Melayu. Secara keseluruhannya, 4.5\% (95\% CI: 4.2-4.8) pesakit mencapai semua sasaran ABC. Berbanding dengan kumpulan umur $\geq 60$ tahun, didapati bahawa pesakit dalam kumpulan umur 18-44 dan 45-59 masing-masing mempunyai 0.50 dan 0.72 nisbah ganjil terlaras untuk mencapai semua sasaran ABC. Kumpulan etnik, indeks jisim badan, mod rawatan diabetes, ubat lipid dan polifarmasi adalah faktor tidak bersandar yang berkaitan dengan keputusan kajian ini. Kesimpulannya, pencapaian semua sasaran ABC bagi pesakit T2D merupakan satu cabaran, terutamanya dalam kalangan golongan muda. Hasil kajian kami menunjukkan bahawa intervensi perlu disasarkan terhadap golongan yang berisiko tinggi ini.

Kata kunci: Diabetes jenis dua; hemoglobin A1C; kesihatan primer; kolesterol; tekanan darah 


\section{INTRODUCTION}

Cerebrovascular and ischemic heart diseases are the top two causes of death in Malaysia, contributing to 15.2 and $14.8 \%$ of the total deaths, respectively (Institute for Public Health 2017). Meanwhile, type 2 diabetes (T2D) confers about a two-fold added risk of developing these cardiovascular diseases (CVD) (The Emerging Risk Factors Collaboration 2010). Clinical guidelines on the management of diabetes patients have recommended the achievement of treatment goals for glycated haemoglobin $\mathrm{A} 1 \mathrm{C}$, blood pressure (BP), and LDL-cholesterol (LDL-C) ('ABC') to prevent diabetes complications (Ministry of Health Malaysia 2015).

The beneficial effects of achieving the treatment goals were incremental in a dose-related manner. Diabetes patients who achieved one, two, and all three ABC goals had lower CVD event risks by 36, 52, and $62 \%$, respectively, compared to those who attained zero goals (Wong et al. 2016). In a population-based retrospective cohort study with 144,271 T2D patients, those who attained one, two, and all three ABC goals had incremental reductions in CVD incidences (Wan et al. 2017).

Despite the clear benefits of attaining all three $\mathrm{ABC}$ goals, the proportion of diabetes patients who achieved these goals concurrently were under $10 \%$ in many studies (Chew et al. 2013; Stone et al. 2013; Wan et al. 2017; Wong et al. 2016).

A Malaysian study conducted in 2008-2009 reported that less than $2 \%$ of T2D patients achieved all three $\mathrm{ABC}$ goals. The findings were at $1.8 \%$ for older adults aged $\geq 60$ years and $1.0 \%$ for patients $<60$ years (Chew et al. 2013). Other studies had also shown similar differences between age groups, whereby younger adults underperformed compared to their older counterparts (Goh et al. 2018; Wong et al. 2016).

It is important in the emerging practice of precision public health to granularly predict public health risks and customise interventions for more specific and homogeneous sub-populations (Dolley 2018). Essentially, delivering the right intervention at the right time and to the right population is the goal. However, we find a paucity of information on the attainment of all three ABC goals among diabetes patients over the past decade in Malaysia. Moreover, factors associated with the achievement of all three $\mathrm{ABC}$ goals are unknown in the local context. Hence, we aim to determine the proportion of T2D patients who achieved all the ABC goals in Malaysia's public health clinics. In addition, we also aim to determine the association between age groups with the attainment of all the $\mathrm{ABC}$ goals.

\section{MATERIALS AND METHODS}

\section{STUDY DESIGN AND SOURCE OF DATA}

This was a cross-sectional analysis of the baseline findings from a retrospective open cohort study between 2013 and 2017 in Negeri Sembilan, Malaysia. The data was extracted from the National Diabetes Registry, which had two components: the 'registry dataset' and the 'clinical audit dataset'. The 'registry dataset' contained information on registration, demographics and follow-up status. The annual 'clinical audit dataset' was formed when a subset of T2D patients in public health clinics was randomly sampled. This clinical audit dataset contained information on clinical variables, complications and treatments (Ministry of Health Malaysia 2020b). The study participants were patients with T2D, aged 18 years and above, and had at least two clinical audits within the study period. Patients with established CVD were excluded.

\section{STUDY DEFINITIONS}

The baseline information gathered were demographic factors, smoking status, comorbidities, diabetes complications and treatment profiles. The patients were categorised into $18-44,45-59$, and $\geq 60$ years old. The $<45$ years category was chosen in accordance to the definition of early-onset T2D (Wilmot \& Idris 2014). Older adults were patients aged $\geq 60$ years based on the United Nations' definition (United Nations 2017). Other demographic factors were sex and ethnicity. Smoking status referred to whether patients had ever smoked.

The comorbidities were overweight or obese based on the World Health Organization body mass index (BMI) classification (World Health Organization 2000), hypertension was defined as that diagnosed clinically or patients on antihypertensive agents, and dyslipidaemia was a clinical diagnosis or patients on lipid-lowering agents. Diabetes complications, namely retinopathy, nephropathy and foot complications (foot ulcer or amputation) were based on clinical diagnoses. The treatment profiles noted were the diabetes treatment modality, the number of antihypertensive agents, the use of lipid-lowering agents, and antiplatelet agents. Polypharmacy was defined as using five or more types of pharmacological agents (Masnoon et al. 2017).

The attainment of all the $\mathrm{ABC}$ goals was defined as achieving A1C of $<7.0 \%$, BP of $<130 / 80 \mathrm{mmHg}$ and LDL-C of $<2.6 \mathrm{mmol} / \mathrm{L}$. These treatment goals followed the 2012 Standards of Medical Care in Diabetes by the American Diabetes Association (American Diabetes Association 2012). 


\section{STATISTICAL ANALYSIS}

Patients' baseline characteristics were described using frequencies and percentages for categorical variables. Continuous variables were presented using mean \pm standard deviation (SD) or median with interquartile range (IQR), depending on the data distribution. For comparisons between age groups, the Pearson chisquare tests were used to compare proportions, whereas the parametric one-way ANOVA and non-parametric Kruskal-Wallis tests were carried out for continuous variables. In the univariate analysis, we conducted the Pearson chi-square tests to compare the proportion of patients who attained all the $\mathrm{ABC}$ goals. Multivariate binary logistic regression analysis was carried out for variables with $P$-values $<0.25$ and clinically important variables. The forward stepwise likelihood ratio (LR) method was applied, and the Omnibus test of model coefficients was used to check the model against the baseline model. The coefficient of determination, $\mathrm{R}^{2}$ and Hosmer \& Lemeshow test of goodness of fit were determined. The model's predictive power was assessed using the classification table and area under the Receiver Operating Characteristic (ROC) curve. Multicollinearity and interactions were also assessed in the multivariate model. The adjusted odds ratios with $95 \%$ confidence intervals were reported. All the tests were two-tailed and statistical significance was pre-set at $P<0.05$.

For sensitivity analysis, we repeated the aforementioned analyses for a subgroup of patients with individualised $\mathrm{A} 1 \mathrm{C}$ goal of below $8 \%$, which was recommended for older patients with limited life expectancy, those with extensive comorbidities or complications, or patients with long-standing diabetes (American Diabetes Association 2012). Limited life expectancy was operationally defined for patients aged 75 years and above as the average life expectancy in Malaysia was 74.5 years (Department of Statistics
Malaysia 2019). We defined extensive comorbidities or complications as having three or more comorbidities or complications. Meantime, long-standing diabetes meant diabetes duration for more than 20 years (Cahn et al. 2015). All analyses were carried out using the IBM SPSS Statistical Software, version 23.

\section{ETHICS}

Ethical approval and waiver of written informed consent were obtained from the Malaysian Medical Research Ethics Committee (Reference number: NMRR18-2731-44032). The permission to use secondary data was granted by the State Health Department of Negeri Sembilan. All records were anonymised before being analysed.

\section{RESULTS}

\section{BASELINE CHARACTERISTICS OF PATIENTS}

Almost half of the 17,592 eligible patients were older adults with a mean age of $59.1 \pm 10.6$ years (Table 1). The patients consisted of $56.3 \%$ females, $64.9 \%$ Malays and $93.8 \%$ non-smokers. The median duration of patients diagnosed with diabetes was five years, with an interquartile range of seven years. The comorbidities among the patients were high, whereby about $70 \%$ were overweight or obese, $83.0 \%$ had hypertension, and $78.4 \%$ had dyslipidaemia. About 5.4, 2.7 and $0.9 \%$ of the patients reported having diabetes nephropathy, retinopathy, and foot complications, respectively. More than one-quarter of the patients required insulin treatment, either alone or in combination with oral hypoglycaemic agents (OHA). About half of them required more than one antihypertensive agent. Additionally, $72.1 \%$ of the patients used lipid-lowering agents, while $28.9 \%$ were on antiplatelet agents. Collectively, $43.6 \%$ of the patients had polypharmacy.

TABLE 1. Baseline characteristics of patients

\begin{tabular}{llc}
\hline Characteristics & & $\mathrm{n}(\%)$ \\
\hline \multirow{2}{*}{ Sex } & Male & $7,690(43.7)$ \\
& Female & $9,902(56.3)$ \\
& Mean \pm standard deviation, years & $59.1 \pm 10.6$ \\
Age & $18-44$ years & $1,482(8.4)$ \\
& $45-59$ years & $7,559(43.0)$ \\
& $\geq 60$ years & $8,551(48.6)$
\end{tabular}




\begin{tabular}{|c|c|c|}
\hline \multirow{4}{*}{ Ethnicity } & Malay & $11,413(64.9)$ \\
\hline & Chinese & 2,615 (14.9) \\
\hline & Indian & $3,449(19.6)$ \\
\hline & Others & $116(0.7)$ \\
\hline \multirow{4}{*}{ Duration of diabetes } & Median (IQR), years & $5.0(7.0)$ \\
\hline & $<5$ years & $8,162(46.4)$ \\
\hline & $5-10$ years & $6,298(35.8)$ \\
\hline & $>10$ years & $3,132(17.8)$ \\
\hline \multirow[t]{2}{*}{ Smoker } & & $1,098(6.2)$ \\
\hline & Mean \pm standard deviation, $\mathrm{kg} / \mathrm{m}^{2}$ & $28.0 \pm 5.1$ \\
\hline \multirow{4}{*}{ BMI category $(n=16,834)$} & Normal $\left(18.5\right.$ to $\left.24.9 \mathrm{~kg} / \mathrm{m}^{2}\right)$ & $4,557(25.9)$ \\
\hline & Underweight $\left(<18.5 \mathrm{~kg} / \mathrm{m}^{2}\right)$ & $196(1.1)$ \\
\hline & Overweight ( 25.0 to $29.9 \mathrm{~kg} / \mathrm{m}^{2}$ ) & $6,810(38.7)$ \\
\hline & Obese $\left(\geq 30.0 \mathrm{~kg} / \mathrm{m}^{2}\right)$ & $5,271(30.0)$ \\
\hline Hypertension & & $14,599(83.0)$ \\
\hline Dyslipidaemia & & $13,792(78.4)$ \\
\hline Nephropathy & & $944(5.4)$ \\
\hline Retinopathy & & $482(2.7)$ \\
\hline \multirow{2}{*}{ Foot complication } & & $161(0.9)$ \\
\hline & Lifestyle modification only & $444(2.5)$ \\
\hline \multirow{3}{*}{ Diabetes treatment modality } & Oral hypoglycaemic agent (OHA) only & $12,306(70.0)$ \\
\hline & Insulin only & $1,041(5.9)$ \\
\hline & Both OHA and insulin & $3,800(21.6)$ \\
\hline \multirow{4}{*}{ Number of antihypertensive agents } & None & $3,483(19.8)$ \\
\hline & One & $5,231(29.7)$ \\
\hline & Two & $5,193(29.5)$ \\
\hline & Three or more & $3,685(21.0)$ \\
\hline Lipid-lowering agents & & $12,688(72.1)$ \\
\hline Antiplatelet agents & & $5,092(28.9)$ \\
\hline Polypharmacy & & $7,673(43.6)$ \\
\hline
\end{tabular}

IQR, interquartile range; OHA, oral hypoglycaemic agents

\section{CHARACTERISTICS OF PATIENTS BY AGE GROUPS}

There were a higher proportion of patients who were males, of Chinese ethnicity, were non-smokers, and with normal bodyweight among the older adult patients aged $\geq 60$ years (Table 2 ). The proportion of patients with hypertension, dyslipidaemia, and diabetes complications increased as the age increased. Similarly, the use of antihypertensive, lipid-lowering, antiplatelet agents and polypharmacy significantly increased as the group got older. However, the pattern was reversed for diabetes treatment modality, whereby lifestyle modifications without any pharmacological agents were more common among older adults, while the concurrent use of insulin and OHA was higher in younger adults. 
TABLE 2. Characteristics of patients by age groups

\begin{tabular}{|c|c|c|c|c|}
\hline \multirow[t]{2}{*}{ Characteristics } & $\begin{array}{l}\text { Age 18-44 years } \\
\text { n (column \%) }\end{array}$ & $\begin{array}{c}\text { Age } 45-59 \text { years } \\
\text { n (column \%) }\end{array}$ & $\begin{array}{l}\text { Age } \geq 60 \text { years } \\
\text { n (column \%) }\end{array}$ & \multirow[t]{2}{*}{$\begin{array}{c}P \text { - } \\
\text { values }\end{array}$} \\
\hline & $1,482(8.4)$ & $7,560(43.0)$ & $8,550(48.6)$ & \\
\hline \multicolumn{5}{|l|}{ Sex } \\
\hline Male & $596(40.2)$ & $3,148(41.6)$ & $3,946(46.2)$ & \multirow{2}{*}{$<0.001$} \\
\hline Female & $886(59.8)$ & $4,412(58.4)$ & $4,604(53.8)$ & \\
\hline \multicolumn{5}{|l|}{ Age } \\
\hline Mean $\pm \mathrm{SD}$, years & $38.9 \pm 4.8$ & $53.4 \pm 4.0$ & $67.6 \pm 6.3$ & $<0.001^{*}$ \\
\hline \multicolumn{5}{|l|}{ Ethnicity } \\
\hline Malay & 927 (62.6) & $5,082(67.2)$ & $5,404(63.2)$ & \multirow{4}{*}{$<0.001$} \\
\hline Chinese & $122(8.2)$ & $769(10.2)$ & $1,723(20.2)$ & \\
\hline Indian & $403(27.2)$ & $1,645(21.8)$ & $1,400(16.4)$ & \\
\hline Others & $30(2.0)$ & $63(0.8)$ & $23(0.3)$ & \\
\hline \multicolumn{5}{|l|}{ Duration of diabetes } \\
\hline Median (IQR), years & $3.0(4.0)$ & $4.0(6.0)$ & $6.0(7.0)$ & \\
\hline$<5$ years & $996(67.2)$ & $3,803(50.3)$ & $3,362(39.3)$ & $<0.001 \uparrow$ \\
\hline $5-10$ years & $407(27.5)$ & $2,722(36.0)$ & $3,169(37.1)$ & \multirow[t]{2}{*}{$<0.001$} \\
\hline$>10$ years & $79(5.3)$ & $1,034(13.7)$ & $2,020(23.6)$ & \\
\hline \multicolumn{5}{|l|}{ Smoker } \\
\hline Yes & $109(7.4)$ & $511(6.8)$ & $477(5.6)$ & \multirow{2}{*}{0.001} \\
\hline No & $1,373(92.6)$ & $7,048(93.2)$ & $8,074(94.4)$ & \\
\hline \multicolumn{5}{|l|}{ Body mass index, } \\
\hline \multicolumn{5}{|l|}{$\mathrm{n}=16,834$} \\
\hline Mean $\pm \mathrm{SD}, \mathrm{kg} / \mathrm{m}^{2}$ & $30.3 \pm 6.1$ & $28.8 \pm 5.1$ & $26.9 \pm 4.6$ & \multirow{4}{*}{$\begin{array}{l}<0.001 * \\
<0.001\end{array}$} \\
\hline Underweight & $12(0.8)$ & $36(0.5)$ & $148(1.8)$ & \\
\hline Normal weight & $245(17.2)$ & $1,601(22.0)$ & $2,711(33.3)$ & \\
\hline Overweight & $484(34.0)$ & $2,964(40.8)$ & $3,361(41.3)$ & \\
\hline Obese & $681(47.9)$ & $2,670(36.7)$ & $1,921(23.6)$ & \\
\hline \multicolumn{5}{|l|}{ Hypertension } \\
\hline Yes & $867(58.5)$ & $5,989(79.2)$ & 7,743 (90.6) & \multirow{2}{*}{$<0.001$} \\
\hline No & $615(41.5)$ & $1,570(20.8)$ & $808(9.4)$ & \\
\hline \multicolumn{5}{|l|}{ Dyslipidaemia } \\
\hline Yes & $951(64.2)$ & $5,876(77.7)$ & $6,965(81.5)$ & \multirow{2}{*}{$<0.001$} \\
\hline No & $531(35.8)$ & $1,683(22.3)$ & $1,586(18.5)$ & \\
\hline \multicolumn{5}{|l|}{ Diabetes nephropathy } \\
\hline Yes & $42(2.8)$ & $288(3.8)$ & $614(7.2)$ & \multirow{2}{*}{$<0.001$} \\
\hline No & $1,440(97.2)$ & $7,272(96.2)$ & $7,937(92.8)$ & \\
\hline
\end{tabular}




\begin{tabular}{|c|c|c|c|c|}
\hline \multirow[t]{2}{*}{ Characteristics } & $\begin{array}{c}\text { Age 18-44 years } \\
\text { n (column \%) }\end{array}$ & $\begin{array}{c}\text { Age } 45-59 \text { years } \\
\text { n (column \%) }\end{array}$ & $\begin{array}{c}\text { Age } \geq 60 \text { years } \\
\text { n (column } \%)\end{array}$ & \multirow{2}{*}{$\begin{array}{c}P \text { - } \\
\text { values }\end{array}$} \\
\hline & $1,482(8.4)$ & $7,560(43.0)$ & $8,550(48.6)$ & \\
\hline \multicolumn{5}{|c|}{ Diabetes retinopathy } \\
\hline Yes & $19(1.3)$ & $158(2.1)$ & $305(3.6)$ & \multirow{2}{*}{$<0.001$} \\
\hline No & $1,463(98.7)$ & 7,401 (97.9) & $8,246(96.4)$ & \\
\hline \multicolumn{5}{|c|}{ Diabetes foot complication } \\
\hline Yes & $10(0.7)$ & $65(0.9)$ & $86(1.0)$ & \multirow{2}{*}{0.372} \\
\hline No & $1,473(99.3)$ & 7,494 (99.1) & $8,464(99.0)$ & \\
\hline \multicolumn{5}{|c|}{ Diabetes treatment modality } \\
\hline Lifestyle modifi & $25(17)$ & $157(21)$ & $260(30)$ & \multirow{4}{*}{$<0.001$} \\
\hline OHA only & 977 (65.9) & $5,129(67.8)$ & $6,204(72.6)$ & \\
\hline \multirow{2}{*}{ Both OHA and } & $97(6.5)$ & $354(4.7)$ & $590(6.9)$ & \\
\hline & $383(25.8)$ & $1,920(25.4)$ & $1,497(17.5)$ & \\
\hline \multicolumn{5}{|c|}{ Number of antihypertensive agents } \\
\hline None & $663(44.7)$ & $1,779(23.5)$ & $1,041(12.2)$ & \multirow{4}{*}{$<0.001$} \\
\hline Two & $451(30.4)$ & $2,301(30.5)$ & $2,479(29.0)$ & \\
\hline \multirow{2}{*}{ Three or more } & $243(16.4)$ & $2,132(28.2)$ & $2,818(33.9)$ & \\
\hline & $125(8.4)$ & $1,347(17.8)$ & $2,212(25.8)$ & \\
\hline \multicolumn{5}{|c|}{ Use of lipid-lowering agent } \\
\hline Yes & 868 (58.6) & $5,402(71.5)$ & $6,417(75.1)$ & \multirow{2}{*}{$<0.001$} \\
\hline No & $614(41.4)$ & $2,158(28.5)$ & $2,133(24.9)$ & \\
\hline \multicolumn{5}{|c|}{ Use of antiplatelet agent } \\
\hline Yes & 217 (14.6) & $1,984(26.2)$ & $2,890(33.8)$ & \multirow{2}{*}{$<0.001$} \\
\hline No & $1,265(85.4)$ & $5,575(73.8)$ & $5,660(66.2)$ & \\
\hline \multicolumn{5}{|l|}{ Polypharmacy } \\
\hline Yes & 324 (21.9) & $3,124(41.3)$ & $4,225(49.4)$ & \multirow{2}{*}{$<0.001$} \\
\hline No & $1,158(78.1)$ & $4,435(58.7)$ & $4,326(50.6)$ & \\
\hline
\end{tabular}

IQR, interquartile range; OHA, oral hypoglycaemic agents; SD, standard deviation, Pearson Chi-square test was used to compare the proportions, *One-way ANOVA test, $\dagger$ Kruskal-Wallis test

\section{ATTAINMENT OF ABC GOALS}

The mean $\mathrm{ABC}$ results were $7.87 \pm 2.02 \%$ for $\mathrm{A} 1 \mathrm{C}, 134.8 \pm$ $16.7 \mathrm{mmHg}$ for systolic $\mathrm{BP}, 78.3 \pm 9.4 \mathrm{mmHg}$ for diastolic $\mathrm{BP}$, and $2.91 \pm 0.94 \mathrm{mmol} / \mathrm{L}$ for LDL-C. Figure 1 shows that $42.0 \%$ of the patients attained an $\mathrm{A} 1 \mathrm{C}$ of $<7 \%, 22.3 \%$ had BP of $<130 / 80 \mathrm{mmHg}$, and $38.1 \%$ achieved an LDL-C of $<2.6 \mathrm{mmol} / \mathrm{L}$. Overall, only $4.5 \%$ (95\% CI: $4.2-4.8)$ attained all the $\mathrm{ABC}$ goals. The achievement of all three $\mathrm{ABC}$ goals by age groups were reported as $2.5 \%(95 \%$ CI: $1.8-3.4)$ for $18-44$ years, $3.6 \%$ (95\% CI: $3.2-4.1)$ for 


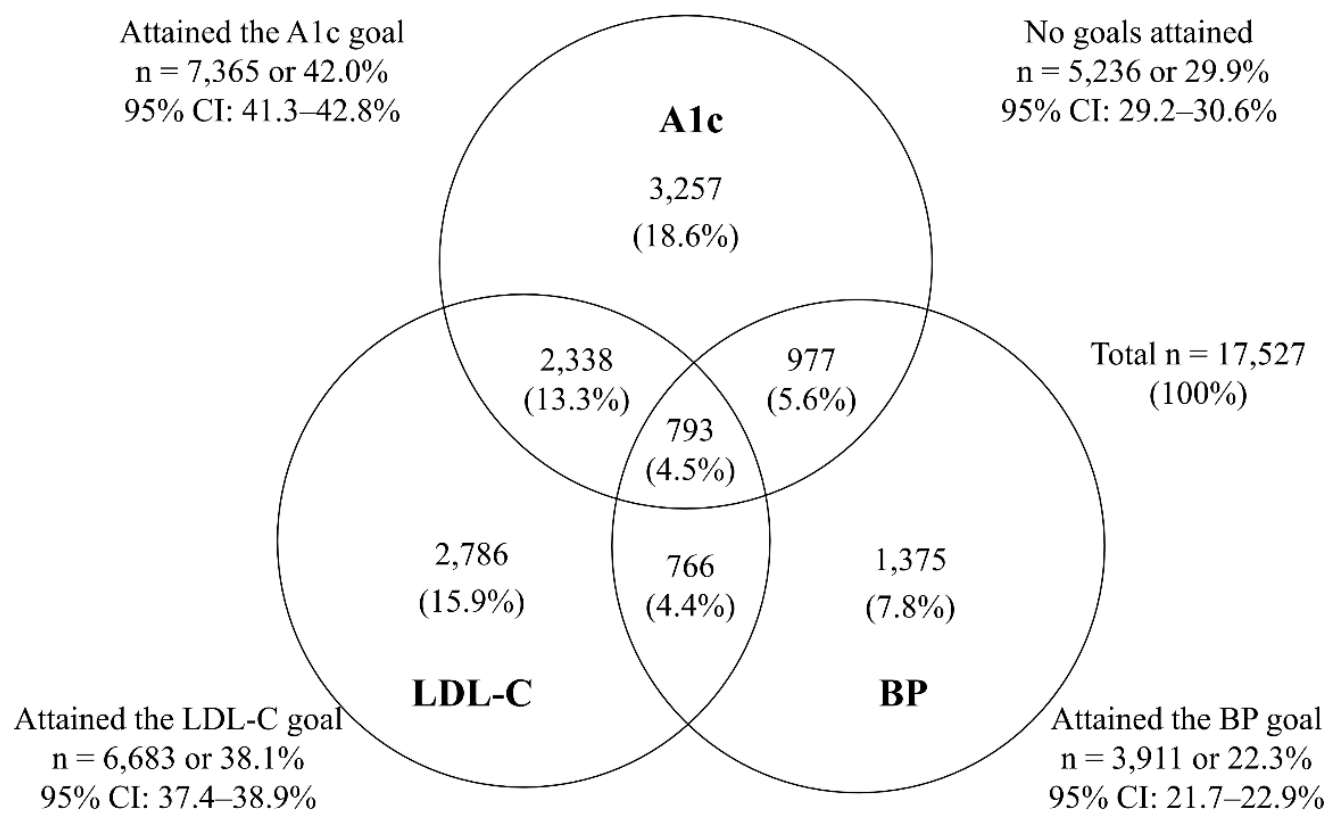

FIGURE 1. Venn diagram showing the proportions of patients who attained their A1C, BP, and LDL-C goals

45-59 years, and 5.7\% (95\% CI: 5.2-6.2) for $\geq 60$ years, with $X^{2}(2, \mathrm{~N}=17,527)=53.7, P<0.001$.

\section{ASSOCIATION BETWEEN AGE GROUPS WITH THE ATTAINMENT OF ALL THREE ABC GOALS}

In the multivariate analysis, underweight patients of Chinese and Indian ethnicity, and those on lipid-lowering agents were associated with higher odds of attaining all three ABC goals (Table 3). On the other hand, younger adults, overweight or obese patients, those treated with insulin (alone or in combination with OHA), and polypharmacy users were less likely to achieve the intended outcome. In a dose-related manner, the younger the age group, the lower the adjusted odds to achieve all the ABC goals.

\section{SENSITIVITY ANALYSIS: INDIVIDUALISED A1C GOAL}

Among the 7,580 patients with an individualised A1C goal of $<8 \%$, they were mainly females, older adults, of Malay ethnicity, and non-smokers (Table 4). About $85 \%$ of these patients were overweight or obese, $98.2 \%$ had hypertension, and almost $95 \%$ had dyslipidaemia. Diabetes complications occurred in 1.6 to $11.0 \%$ of the patients. More than $30 \%$ of the patients were treated with insulin, either alone or in combination with OHA. Around 95 and $87 \%$ of the patients were treated with antihypertensive and lipid-lowering agents, respectively. Meanwhile, onethird of the patients were prescribed with antiplatelet agents, and $58.0 \%$ of them had polypharmacy.

Figure 2 shows that $62.0 \%$ of the patients attained individualised $\mathrm{A} 1 \mathrm{C}$ of $<8 \%, 19.4 \%$ had a BP of $<130 / 80$ $\mathrm{mmHg}$, and $41.3 \%$ achieved a LDL-C of $<2.6 \mathrm{mmol} / \mathrm{L}$. In entirety, 6.1\% (95\% CI: 5.6-6.7) attained all three $\mathrm{ABC}$ goals, which was marginally higher than $4.5 \%$ in the primary analysis. The achievements of all three ABC goals by age groups were reported as 3.2\% (95\% CI: 1.64.9) for $18-44$ years, $4.2 \%$ (95\% CI: $3.5-4.9)$ for $45-59$ years, and $7.8 \%$ (95\% CI: 7.0-8.7) for $\geq 60$ years, with $X^{2}(2, N=7,555)=47.2, P<0.001$. These results were marginally higher than those in the primary analysis for all age groups. 
TABLE 3. Multiple logistic regression model for the attainment of all three $\mathrm{ABC}$ goals, $\mathrm{n}=16,779$

\begin{tabular}{|c|c|c|c|}
\hline Characteristics & Adjusted OR & $95 \% \mathrm{CI}$ for adjusted OR & $P$-values \\
\hline \multicolumn{4}{|l|}{ Age } \\
\hline $18-44$ years & 0.50 & 035,071 & $<0001$ \\
\hline $45-59$ years & 0.72 & $0.00-0.11$ & 0.001 \\
\hline$\geq 60$ years & 1.00 & $0.62-0.85$ & $<0.001$ \\
\hline \multicolumn{4}{|l|}{ Ethnicity } \\
\hline Chinese & 1.80 & $1.50-2.17$ & $<0.001$ \\
\hline Malay & 1.00 & & \\
\hline Indian & 1.26 & $1.04-1.53$ & 0.019 \\
\hline Others & 1.45 & $0.70-3.00$ & 0.311 \\
\hline \multicolumn{4}{|l|}{ BMI class } \\
\hline Underweight & 2.13 & $1.37-3.32$ & 0.001 \\
\hline Normal weight & 1.00 & & \\
\hline Overweight & 0.69 & $0.58-0.82$ & $<0.001$ \\
\hline Obese & 0.68 & $0.56-0.83$ & $<0.001$ \\
\hline \multicolumn{4}{|l|}{ Diabetes treatment modality } \\
\hline Lifestyle modification only & 0.76 & $0.49-1.20$ & 0.237 \\
\hline OHA only & 1.00 & & \\
\hline Insulin only & 0.45 & $0.30-0.68$ & $<0.001$ \\
\hline Both OHA and insulin & 0.29 & $0.22-0.39$ & $<0.001$ \\
\hline Lipid-lowering agent & 1.20 & $1.01-1.42$ & 0.041 \\
\hline Polypharmacy use & 0.66 & $0.56-0.78$ & $<0.001$ \\
\hline
\end{tabular}

OHA, oral hypoglycaemic agents, Omnibus tests of model coefficients $(P<0.001)$, Hosmer-Lemeshow goodness of fit test $(P=0.644)$, classification table (overall correct percentage: $95.5 \%), 2 \log$ likelihood (5,815.2), Nagelkerke R square (0.06), Area under receiving operating characteristics, ROC curve: 0.67 , standard error $0.008, P<0.001$ and $95 \%$ CI: $0.65-0.68$

In the adjusted analysis model, age groups, ethnicity, diabetes treatment modality and polypharmacy usage were independent factors associated with the attainment of all the $\mathrm{ABC}$ goals, which was similar to the primary analysis (Table 5). Younger adults, patients on insulin treatment and polypharmacy users were significantly less likely to achieve the intended outcome. Similarly, the younger the age group, the lower the adjusted odds to achieve all three $\mathrm{ABC}$ goals. Additionally, compared to the Malay ethnic group, Chinese and Indian patients were more likely to attain all three $\mathrm{ABC}$ goals. The outcome of the sensitivity analysis using the individualised A1C goal was consistent with the primary findings of this study. 
TABLE 4. Characteristics of patients with individualised A1C goal $<8 \%, n=7,580$

\begin{tabular}{|c|c|c|}
\hline Characteristics & & $\mathrm{n}(\%)$ \\
\hline \multirow{3}{*}{ Sex } & Male & $3,190(42.1)$ \\
\hline & Female & $4,390(57.9)$ \\
\hline & Mean \pm standard deviation, years & $61.5 \pm 11.2$ \\
\hline \multirow{4}{*}{ Age } & $18-44$ years & $434(5.7)$ \\
\hline & $45-59$ years & $2,982(39.3)$ \\
\hline & $\geq 60$ years & $4,164(54.9)$ \\
\hline & Malay & $5,146(67.9)$ \\
\hline \multirow{4}{*}{ Ethnicity } & Chinese & $1,122(14.8)$ \\
\hline & Indian & $1,266(16.7)$ \\
\hline & Others & $45(0.6)$ \\
\hline & Median (IQR) & $6.0(7.0)$ \\
\hline \multirow{3}{*}{ Duration of diabetes } & $<5$ years & $3,074(40.6)$ \\
\hline & $5-10$ years & $2,822(37.2)$ \\
\hline & $>10$ years & $1,684(22.2)$ \\
\hline Smoker & & $435(5.7)$ \\
\hline \multirow{5}{*}{ BMI category $(n=7,448)$} & Mean \pm standard deviation & $30.3 \pm 5.1$ \\
\hline & Normal (18.5 to $\left.24.9 \mathrm{~kg} / \mathrm{m}^{2}\right)$ & $897(11.8)$ \\
\hline & Underweight $\left(<18.5 \mathrm{~kg} / \mathrm{m}^{2}\right)$ & $76(1.0)$ \\
\hline & Overweight ( 25.0 to $29.9 \mathrm{~kg} / \mathrm{m}^{2}$ ) & $2,668(35.2)$ \\
\hline & Obese $\left(\geq 30.0 \mathrm{~kg} / \mathrm{m}^{2}\right)$ & $3,808(50.2)$ \\
\hline Hypertension & & $7,440(98.2)$ \\
\hline Dyslipidaemia & & $7,178(94.7)$ \\
\hline Nephropathy & & $834(11.0)$ \\
\hline Retinopathy & & $419(5.5)$ \\
\hline Foot complication & & $122(1.6)$ \\
\hline \multirow{4}{*}{ Diabetes treatment modality } & Lifestyle modification only & $190(2.5)$ \\
\hline & Oral hypoglycaemic agent (OHA) only & $5,022(66.3)$ \\
\hline & Insulin only & $563(7.4)$ \\
\hline & Both OHA and insulin & $1,806(23.8)$ \\
\hline \multirow{4}{*}{ Number of antihypertensive agents } & None & $354(4.7)$ \\
\hline & One & $2,430(32.1)$ \\
\hline & Two & $2,680(35.4)$ \\
\hline & Three or more & $2,116(27.9)$ \\
\hline Lipid-lowering agents & & $6,599(87.1)$ \\
\hline Antiplatelet agents & & $2,567(33.9)$ \\
\hline Polypharmacy & & $4,398(58.0)$ \\
\hline
\end{tabular}

IQR, interquartile range; OHA, oral hypoglycaemic agents 


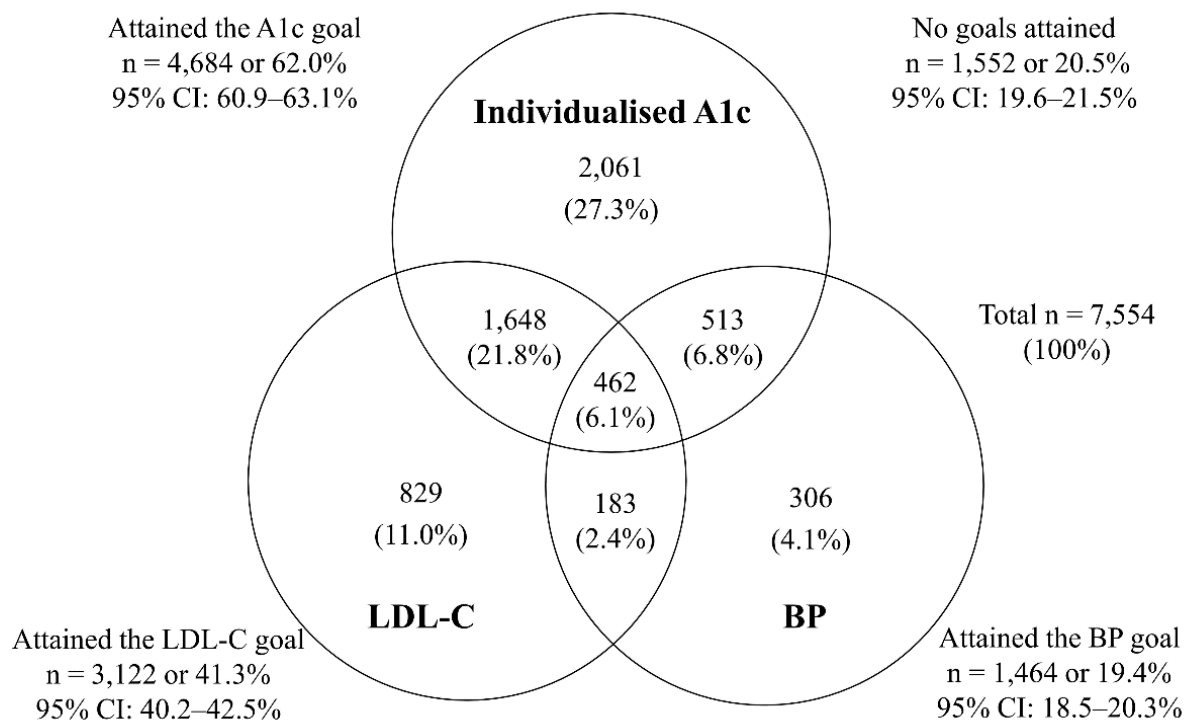

FIGURE 2. Venn diagram showing the proportions of patients who attained their individualised A1C, BP, and LDL-C goals

TABLE 5. Multiple logistic regression model for attainment of all individualised A1C, BP, and LDL-C goals, $\mathrm{n}=7,474$

\begin{tabular}{|c|c|c|c|}
\hline Characteristics & Adjusted OR & $95 \%$ CI for adjusted OR & $P$-values \\
\hline \multicolumn{4}{|l|}{ Age } \\
\hline $18-44$ years & 0.43 & & \\
\hline $45-59$ years & 0.58 & $0.24-0.15$ & 0.003 \\
\hline$\geq 60$ years & 1.00 & $0.47-0.72$ & $<0.001$ \\
\hline \multicolumn{4}{|l|}{ Ethnicity } \\
\hline Chinese & 1.90 & $1.49-2.41$ & $<0.001$ \\
\hline Malay & 1.00 & & \\
\hline Indian & 1.48 & $1.14-1.91$ & 0.003 \\
\hline Others & 1.56 & $0.44-5.59$ & 0.493 \\
\hline \multicolumn{4}{|l|}{ Diabetes treatment modality } \\
\hline Lifestyle modification only & 0.83 & $0.47-1.48$ & 0.527 \\
\hline OHA only & 1.00 & & \\
\hline Insulin only & 0.45 & $0.28-0.72$ & 0.001 \\
\hline Both OHA and insulin & 0.37 & $0.27-0.51$ & $<0.001$ \\
\hline Polypharmacy use & 0.75 & $0.61-0.91$ & 0.004 \\
\hline
\end{tabular}

OHA, oral hypoglycaemic agents, Omnibus tests of model coefficients $(P<0.001)$, Hosmer-Lemeshow goodness of fit test $(P=0.877)$, classification table (overall correct percentage: $94.0 \%), 2 \log$ likelihood $(3,229.0)$, Nagelkerke R square (0.06), Area under receiving operating characteristics, ROC curve: 0.67 , standard error $0.01, P<0.001$ and $95 \%$ CI: $0.64-0.69$ 


\section{DISCUSSION \\ ABC TREATMENT GOALS}

This study's treatment goals followed the 2012 Standards of Medical Care in Diabetes by the American Diabetes Association (American Diabetes Association 2012). The cut-off parameters used to define the treatment goals should conceptually set before the study began. The use of newer cut-offs implemented during or after the study period might introduce misclassification biases. In the sensitivity analysis, the individualised $\mathrm{A} 1 \mathrm{C}$ goal was accounted for when the attainment of all $\mathrm{ABC}$ goals was computed. A less stringent $\mathrm{A} 1 \mathrm{C}$ goal of $<8 \%$ was targeted for patients with a limited life expectancy, had advanced diabetes complications, extensive comorbidities, and with long-standing diabetes (American Diabetes Association 2012).

\section{CHARACTERISTICS OF PATIENTS}

The characteristics of patients in this study closely resembled those in the National Diabetes Registry, whereby females, patients of Malay ethnicity, nonsmokers, patients with comorbid hypertension, and dyslipidaemia predominated the study subjects (Ministry of Health Malaysia 2020b). The mean age and median duration of being diabetic were also comparable with the registry's data (Ministry of Health Malaysia 2020b).

\section{ATTAINMENT OF ALL THREE ABC GOALS}

Our results showed that $4.5 \%$ of the patients attained all three $\mathrm{ABC}$ goals. Our findings were comparable to studies done in the USA, Europe, and Hong Kong, whereby the respective achievements were 7.2, 6.5, and 9.3\% (Stone et al. 2013; Wan et al. 2017; Wong et al. 2016). Other studies had reported more encouraging results, such as $11.2 \%$ in Japan and $21.8 \%$ in Singapore (Goh et al. 2018; Hu et al. 2016). However, the definition of treatment goals was different in these studies in which their BP goal was $<140 / 90 \mathrm{mmHg}$ instead of $<130 / 80$ $\mathrm{mmHg}$, targeted in our study (Goh et al. 2018; Hu et al. 2016). A study in the USA reported that by adopting less stringent $\mathrm{ABC}$ goals, the proportion of patients attaining all three goals increased by almost three-fold, from 16 to $44 \%$ (Schroeder et al. 2012). The current achievement of $4.5 \%$ may reflect improvement, as less than $2 \%$ of Malaysian T2D patients achieved all three ABC goals in 2009 (Chew et al. 2013). Nevertheless, in that study, the A1C cut-off was $\leq 6.5 \%$ instead of $<7 \%$ in our study; hence, the comparison should be cautiously interpreted (Chew et al. 2013). The A1C cut-off of $<7 \%$ used in this study mirrors all major international guidelines and enables a valid comparison between studies (American
Diabetes Association 2020, 2012; Cosentino et al. 2020; Hong Kong Department of Health 2018; International Diabetes Federation 2017).

There are several potential explanations for the suboptimal ABC control in this study. Firstly, it was not biologically attainable for some patients to achieve all three $A B C$ goals due to high disease severity, comorbidities, and complications (Casagrande et al. 2013). A high disease severity may be reflected from the high proportions of insulin treatment and polypharmacy used among our patients. Secondly, a change in the local clinical guidelines in 2015 towards individualising A1C goal may partly explain the low attainment of all three ABC goals (Ministry of Health Malaysia 2015). In selected groups of patients, their A1C goal was aimed at 7.1-8.0\%, and therefore, these patients were not expected to achieve our targeted A1C goal of $<7 \%$ (Ministry of Health Malaysia 2015). Nevertheless, after accounting for individualised $\mathrm{A} 1 \mathrm{C}$ goal in the sensitivity analysis, the achievement of all three ABC goals only improved slightly and remained suboptimal at $6.1 \%$.

Thirdly, patients may lack self-management skills or resources to adhere to a demanding treatment protocol that includes polypharmacy use and lifestyle modifications (Casagrande et al. 2013). However, our study did not capture information on treatment adherence, physical activity level and dietary intake, which are acknowledged as a limitation in the study. Fourthly, clinical inertia, defined as a delay in treatment intensification among patients with poor glycaemic control, can also explain the suboptimal ABC control (Mata-Cases et al. 2016). In support of this possible cause, a recent study in Malaysia has reported evidence of clinical inertia in the management of T2D patients (Wan et al. 2020).

\section{ASSOCIATION BETWEEN AGE GROUPS WITH THE ATTAINMENT OF ALL THREE ABC GOALS}

Our study found that younger patients under-performed their older counterparts in attaining all the ABC goals, similarly as reported in the USA and Singapore (Goh et al. 2018; Wong et al. 2016). This is especially worrying among patients in the 18-44 age group due to their earlier onset and longer lifespan to develop diabetes complications. Previous literature highlighted that earlyonset T2D below the age of 45 years was associated with premature cardiovascular morbidity and mortality (Wilmot \& Idris 2014). The post-clinical trial monitoring of the United Kingdom Prospective Diabetes Study (UKPDS) demonstrated that patients with early tight glycaemic control had a sustained reduction in diabetes complications over the long term (Holman et al. 2008). 
However, the younger adults in our study who had the most to gain may not benefit from this legacy effect (Holman et al. 2008).

Moreover, about $10 \%$ of our female patients were still in their reproductive age. Therefore, their risks of experiencing adverse maternal and neonatal outcomes would increase if they become pregnant while suffering from uncontrolled diabetes and hypertension (Ministry of Health Malaysia 2017). In addition, maternal hyperglycaemia is an independent risk factor for adolescent obesity and young-onset diabetes among their children (Chan et al. 2020). The children of mothers with diabetes also have a higher risk of developing early-onset CVD (Yu et al. 2019).

There are potential reasons for poorer $\mathrm{ABC}$ performance among the younger adults. Younger patients may be less motivated to manage their diabetes due to work commitments and have less time adhering to a healthy lifestyle, medication, and clinic visits (Quah et al. 2013). The younger adults also face psychosocial barriers such as stress, depression, poorer diet, and lower self-efficacy in diabetes care (Gopalan et al. 2020).

In addition, young-onset diabetes had more severe disease progression (Wilmot \& Idris 2014). This group of patients were associated with severe autoimmune and severe insulin-deficient diabetes subtypes, which had the highest A1C trajectory (Ahlqvist et al. 2018). In our study, the highest proportion of insulin usage was observed in patients aged 18-44 years, reflecting a more severe disease at this young age group of patients.

Another probable explanation behind the poorer attainment of $\mathrm{ABC}$ goals among our younger patients is the cohort effect. This effect is defined as the variation in the risk of a health outcome according to the year of birth (Keyes et al. 2010). In recent decades, economic development and urbanisation have changed the dietary habits and lifestyle of Malaysians (Noor 2002). Prolonged exposure to poor food consumption patterns and minimum physical activity since young are examples of the cohort effect. This may explain why patients aged 18-44 years had the highest proportion of obesity and the poorest attainment of all the ABC goals (Noor 2002). Finally, survival bias may contribute to why older adults better achieved all the $\mathrm{ABC}$ goals (Casagrande et al. 2013).

Younger adults represented a high-risk group with specific issues and needs that can be targeted for intervention (Wilmot \& Idris 2014). For example, most public health clinics in Malaysia only operate during office hours and are less accessible to younger patients who are more likely to be formally employed $(\mathrm{Ng}$ et al. 2017). Hence, telemedicine using telephone, video, or email can facilitate provider-patient interaction at a time that better fits the young patients' schedules (Gopalan et al. 2020).

Furthermore, strengthening actions from the community to create a supportive environment can improve diabetes outcomes (Schmittdiel et al. 2017). Community resources such as workplace-based intervention can be mobilised to meet the younger and working patients' needs (Wagner et al. 2001). In Malaysia, the KOSPEN-Plus programme, translated as 'Healthy Community Builds the Nation', is a nationwide workplace-based non-communicable disease (NCD) risk factor intervention programme that can be leveraged on to reach out to young diabetes patients (Ministry of Health Malaysia 2020a).

Patients of Chinese ethnicity (Lee et al. 2013), with lower BMI (Stone et al. 2013; Wong et al. 2016), and were on lipid-lowering agents (Schroeder et al. 2012; Stone et al. 2013; Wong et al. 2016) were associated with higher odds ratios to attain all the $\mathrm{ABC}$ goals. Attaining all the $\mathrm{ABC}$ goals was associated with fewer diabetes medications (Goh et al. 2018; Schroeder et al. 2012) and not receiving insulin treatment (Schroeder et al. 2012). Our results were largely consistent with these findings. Some limitations are acknowledged in this study. These include information on patients' health-related behaviour, physical activity levels and dietary patterns, which were not captured in the National Diabetes Registry, thus, not made available. Measurement errors may occur with the use of secondary data due to the lack of standardisation in the procedures used to measure the $\mathrm{ABC}$ variables. Nevertheless, this shortfall is likely to be mitigated by existing procedures in the field, such as, using centralised laboratories and scheduled quality control monitoring by relevant authorities.

To the best of our knowledge, this study is among the first in Malaysia to investigate factors associated with the achievement of all three ABC goals among diabetes patients. We identified the demography whereby the younger adults are a high-risk subpopulation who may benefit from clinical and public health interventions to improve their $\mathrm{ABC}$ performance. This study also benefited from a large representative dataset, which increased the power, reduced random error, and yielded more precise confidence intervals. Our findings may be generalised to all diabetes patients attending public health clinics in Malaysia due to sharing similar characteristics. 


\section{CONCLUSION}

In summary, achieving all the $\mathrm{ABC}$ goals in diabetes is a challenge. Only $4.5 \%$ of our T2D patients attained the desired outcome. Notwithstanding their comorbidities and complications, older adults significantly outperformed their younger counterparts. As a result, patients in the 18-44 years category are a high-risk subpopulation. Ethnicity, BMI, diabetes treatment modality, use of lipidlowering agent and polypharmacy were independent factors associated with all the $\mathrm{ABC}$ goals attainment. When individualised A1C goal was accounted for, albeit being slightly improved, the concurrent attainment of individualised A1C, BP, and LDL-C remained suboptimal. Similarly, younger patients have a poorer achievement of all the ABC goals. Based on the current findings, an aggressive and supportive management is recommended in a multidisciplinary setting to prevent diabetes complications in younger adults.

\section{ACKNOWLEDGEMENTS}

We would like to thank the Director-General of Health Malaysia for his permission to publish this article and the State Health Department of Negeri Sembilan for their cooperation. We would also like to acknowledge the Non-Communicable Disease teams for their tireless work managing the National Diabetes Registry.

\section{REFERENCES}

Ahlqvist, E., Storm, P., Käräjämäki, A., Martinell, M., Dorkhan, M., Carlsson, A., Vikman, P., Prasad, R.B., Aly, D.M. \& Almgren, P. 2018. Novel subgroups of adult-onset diabetes and their association with outcomes: a data-driven cluster analysis of six variables. The Lancet Diabetes and Endocrinology 6(5): 361-369.

American Diabetes Association. 2020. 6. Glycemic targets: Standards of medical care in diabetes - 2020. Diabetes Care 43(Supplement 1): S66-S76.

American Diabetes Association. 2012. Standards of medical care in diabetes 2012. Diabetes Care 35(Supplement 1): S11-S63.

Cahn, A., Raz, I., Kleinman, Y., Balicer, R., Hoshen, M., Lieberman, N., Brenig, N., Del Prato, S. \& Cefalu, W.T. 2015. Clinical assessment of individualized glycemic goals in patients with type 2 diabetes: Formulation of an algorithm based on a survey among leading worldwide diabetologists. Diabetes Care 38(12): 2293-2300.

Casagrande, S.S., Fradkin, J.E., Saydah, S.H., Rust, K.F. \& Cowie, C.C. 2013. The prevalence of meeting A1C, blood pressure, and LDL goals among people with diabetes, 19882010. Diabetes Care 36(8): 2271-2279.

Chan, J.C.N., Lim, L.L., Wareham, N.J., Shaw, J.E., Orchard, T.J., Zhang, P., Lau, E.S.H., Eliasson, B., Kong, A.P.S., Ezzati, M., Aguilar-Salinas, C.A., McGill, M., Levitt, N.S., Ning, G., So, W.Y., Adams, J., Bracco, P., Forouhi, N.G.,
Gregory, G.A., Guo, J., Hua, X., Klatman, E.L., Magliano, D.J., Ng, B.P., Ogilvie, D., Panter, J., Pavkov, M., Shao, H., Unwin, N., White, M., Wou, C., Ma, R.C.W., Schmidt, M.I., Ramachandran, A., Seino, Y., Bennett, P.H., Oldenburg, B., Gagliardino, J.J., Luk, A.O.Y., Clarke, P.M., Ogle, G.D., Davies, M.J., Holman, R.R. \& Gregg, E.W. 2020. The Lancet Commission on diabetes: Using data to transform diabetes care and patient lives. The Lancet 396(10267): 2019-2082.

Chew, B.H., Ghazali, S.S., Ismail, M., Haniff, J. \& Bujang, M.A. 2013. Age $\geq 60$ years was an independent risk factor for diabetes-related complications despite good control of cardiovascular risk factors in patients with type 2 diabetes mellitus. Experimental Gerontology 48(5): 485-491.

Cosentino, F., Grant, P.J., Aboyans, V., Bailey, C.J., Ceriello, A., Delgado, V., Federici, M., Filippatos, G., Grobbee, D.E., Hansen, T.B., Huikuri, H.V., Johansson, I., Jüni, P., Lettino, M., Marx, N., Mellbin, L.G., Östgren, C.J., Rocca, B., Roffi, M., Sattar, N., Seferović, P.M., Sousa-Uva, M., Valensi, P., Wheeler, D.C. \& ESC Scientific Document Group. 2020. 2019 ESC Guidelines on diabetes, pre-diabetes, and cardiovascular diseases developed in collaboration with the EASD: The task force for diabetes, pre-diabetes, and cardiovascular diseases of the European Society of Cardiology (ESC) and the European Association for the Study of Diabetes (EASD). European Heart Journal 41(2): 255-323.

Department of Statistics Malaysia. 2019. Abridged Life Tables Malaysia, 2017-2019. https://www.dosm.gov.my/v1/index. php? $\mathrm{r}=$ column/pdfPrev\&id=YnV4S1FyVnNzUWJ1Q3F5N HVMeFY3UT09. Accessed on 24 April 2020.

Dolley, S. 2018. Big data's role in precision public health. Frontiers in Public Health 6(68): 1-12.

Goh, C., Koh, K., Goh, S., Koh, Y. \& Tan, N. 2018. Achieving triple treatment goals in multi-ethnic Asian patients with type 2 diabetes mellitus in primary care. Malaysian Family Physician 13(2): 10-18.

Gopalan, A., Mishra, P., Alexeeff, S.E., Blatchins, M.A., Kim, E., Man, A., Karter, A.J. \& Grant, R.W. 2020. Initial glycemic control and care among younger adults diagnosed with type 2 diabetes. Diabetes Care 43(5): 975-981.

Holman, R.R., Paul, S.K., Bethel, M.A., Matthews, D.R. \& Neil, H.A.W. 2008. 10-year follow-up of intensive glucose control in type 2 diabetes. The New England Journal of Medicine 359: 1577-1589.

Hong Kong Department of Health. 2018. Hong Kong Reference Framework for Diabetes Care for Adults in Primary Care Settings. https://www.fhb.gov.hk/pho/rfs/english/ reference_framework/diabetes_care.html. Accessed on 24 April 2020.

Hu, H., Hori, A., Nishiura, C., Sasaki, N., Okazaki, H., Nakagawa, T., Honda, T., Yamamoto, S., Tomita, K. \& Miyamoto, T. 2016. Hba1c, blood pressure, and lipid control in people with diabetes: Japan epidemiology collaboration on occupational health study. PLoS ONE 11(7): e0159071.

Institute for Public Health. 2017. Malaysian Burden of Disease and Injury Study 2009 - 2014. http://iku.moh.gov.my/ images/IKU/Document/REPORT/BOD/BOD2009-2014.pdf. Accessed on 24 April 2020. 
International Diabetes Federation. 2017. Recommendations for Managing Type 2 Diabetes in Primary Care. https:// idf.org/our-activities/care-prevention/type-2-diabetes.html. Accessed on 24 April 2020.

Keyes, K.M., Utz, R.L., Robinson, W. \& Li, G. 2010. What is a cohort effect? Comparison of three statistical methods for modeling cohort effects in obesity prevalence in the United States, 1971-2006. Social Science and Medicine 70(7): 1100-1108.

Lee, P.Y., Cheong, A.T., Zaiton, A., Mastura, I., Chew, B.H., Sazlina, S.G., Adam, B.M., Syed Alwi, S.A., Jamaiyah, H. \& Sriwahyu, T. 2013. Does ethnicity contribute to the control of cardiovascular risk factors among patients with type 2 diabetes? Asia Pacific Journal of Public Health 25(4): 316-325.

Masnoon, N., Shakib, S., Kalisch-Ellett, L. \& Caughey, G.E. 2017. What is polypharmacy? A systematic review of definitions. BMC Geriatrics 17: 230.

Mata-Cases, M., Franch-Nadal, J., Real, J. \& Mauricio, D. 2016. Glycaemic control and antidiabetic treatment trends in primary care centres in patients with type 2 diabetes mellitus during 2007-2013 in Catalonia: A population-based study. BMJ Open 6(10): e012463.

Ministry of Health Malaysia. 2020a. KOSPEN Plus. https://www. moh.gov.my/index.php/pages/view/kospenplus. Accessed on 15 Janurary 2020.

Ministry of Health Malaysia. 2020b. National Diabetes Registry Report 2013 - 2019. https://www2.moh.gov.my/index.php/ database_stores/attach_download/554/80. Accessed on 30 November 2020.

Ministry of Health Malaysia. 2017. Management of Diabetes in Pregnancy. http://www.acadmed.org.my/index. $\mathrm{cfm} ? \mathrm{menuid}=67$. Accessed on 15 Janurary 2020.

Ministry of Health Malaysia. 2015. Clinical Practice Guidelines for Management of Type 2 Diabetes Mellitus. 5th ed. http:// www.acadmed.org.my/index.cfm?menuid $=67$. Accessed on 15 Janurary 2020.

Ng, C.W., Shahari, M.R., Mariapun, J., Hairi, N.N.M., Rampal, S. \& Mahal, A. 2017. Universal coverage of hypertension treatment services in Malaysia is still an elusive goal. Health Systems and Reform 3(3): 159-170.

Noor, M.I. 2002. The nutrition and health transition in Malaysia. Public Health Nutrition 5(1A): 191-195.

Quah, J.H.M., Liu, Y.P., Luo, N., How, C.H. \& Tay, E.G. 2013. Younger adult type 2 diabetic patients have poorer glycaemic control: A cross-sectional study in a primary care setting in Singapore. BMC Endocrine Disorders 13: 18.

Schmittdiel, J.A., Gopalan, A., Lin, M.W., Banerjee, S., Chau, C.V. \& Adams, A.S. 2017. Population health management for diabetes: Health care system-level approaches for improving quality and addressing disparities. Current Diabetes Reports 17(5): 31 .

Schroeder, E.B., Hanratty, R., Beaty, B.L., Bayliss, E.A., Havranek, E.P. \& Steiner, J.F. 2012. Simultaneous control of diabetes mellitus, hypertension, and hyperlipidemia in 2 health systems. Circulation: Cardiovascular Quality and Outcomes 5(5): 645-653.
Stone, M.A., Charpentier, G., Doggen, K., Kuss, O., Lindblad, U., Kellner, C., Nolan, J., Pazderska, A., Rutten, G. \& Trento, M. 2013. Quality of care of people with type 2 diabetes in eight European countries: Findings from the Guideline Adherence to Enhance Care (GUIDANCE) study. Diabetes Care 36(9): 2628-2638.

The Emerging Risk Factors Collaboration. 2010. Diabetes mellitus, fasting blood glucose concentration, and risk of vascular disease: A collaborative meta-analysis of 102 prospective studies. The Lancet 375(9733): 2215-2222.

United Nations. 2017. World Population Ageing 2015 Highlights. https://www.un.org/en/development/desa/ population/publications/pdf/ageing/WPA2017_Highlights. pdf. Accessed on 24 April 2020

Wagner, E.H., Austin, B.T., Davis, C., Hindmarsh, M., Schaefer, J. \& Bonomi, A. 2001. Improving chronic illness care: Translating evidence into action. Health Affairs 20(6): 64-78.

Wan, E.Y.F., Fung, C.S.C., Yu, E.Y.T., Chin, W.Y., Fong, D.Y.T., Chan, A.K.C. \& Lam, C.L.K. 2017. Effect of multifactorial treatment targets and relative importance of hemoglobin A1c, blood pressure, and low-density lipoprotein-cholesterol on cardiovascular diseases in Chinese primary care patients with type 2 diabetes mellitus: A population-based retrospective cohort study. Journal of the American Heart Association 6(8): e006400.

Wan, K.S., Moy, F.M., Mohd Yusof, K., Mustapha, F.I., Mohd Ali, Z. \& Hairi, N.N. 2020. Clinical inertia in type 2 diabetes management in a middle-income country: A retrospective cohort study. PloS ONE 15(10): e0240531.

Wilmot, E. \& Idris, I. 2014. Early onset type 2 diabetes: Risk factors, clinical impact and management. Therapeutic Advances in Chronic Disease 5(6): 234-244.

Wong, N.D., Zhao, Y., Patel, R., Patao, C., Malik, S., Bertoni, A.G., Correa, A., Folsom, A. R., Kachroo, S. \& Mukherjee, J. 2016. Cardiovascular risk factor targets and cardiovascular disease event risk in diabetes: A pooling project of the Atherosclerosis Risk in communities study, multi-ethnic study of atherosclerosis, and Jackson heart study. Diabetes Care 39(5): 668-676

World Health Organization. 2000. Obesity: Preventing and Managing the Global Epidemic: Report of a WHO Consultation. https://apps.who.int/iris/handle/10665/42330. Accessed on 24 April 2020.

Yu, Y., Arah, O.A., Liew, Z., Cnattingius, S., Olsen, J., Sørensen, H.T., Qin, G. \& Li, J. 2019. Maternal diabetes during pregnancy and early onset of cardiovascular disease in offspring: Population based cohort study with 40 years of follow-up. BMJ 367: 16398

Kim Sui Wan, Noran Naqiah Hairi*, Foong Ming Moy Centre for Epidemiology and Evidence-Based Practice Department of Social and Preventive Medicine Faculty of Medicine University of Malaya Jalan Profesor Diraja Ungku Aziz 50603 Kuala Lumpur, Wilayah Persekutuan Malaysia 
Feisul Idzwan Mustapha

Disease Control Division

Ministry of Health

Level 3 Block E10

Kompleks E, Pusat Pentadbiran Kerajaan Persekutuan

62590 Putrajaya, Wilayah Persekutuan

Malaysia
Khalijah Mohd Yusof, Zainudin Mohd Ali

State Health Department of Negeri Sembilan

Jalan Rasah

70300, Seremban, Negeri Sembilan

Malaysia

*Corresponding author; email: noran@um.edu.my

Received: 13 June 2020

Accepted: 15 April 2021 